\title{
Chronic respiratory failure in severe asthma - Questions answered after biological therapy, a clinical case
}

\section{Insuficiência respiratória crónica na asma grave - Respostas após terapêutica biológica, a propósito de um caso clínico}

RevPort Imunoalergologia 202I;29(3):209-2I3

Joana Branco (iD, Filipa Todo Bom ID, Sofia Furtado iD

Serviço de Pneumologia, Hospital Beatriz Ângelo, Loures, Portugal

\section{ABSTRACT}

Severe asthma is defined as either refractory to traditional therapies or controlled only with therapies that have intolerable side effects. Biological agents are known to offer treatment alternatives to patients with type 2 inflammation severe asthma. We describe the case of a woman with a long history of type 2 inflammation severe asthma, with uncontrolled symptoms and need of systemic corticosteroid therapy as prevailing features, and with respiratory failure that differentiated her from other patients with severe asthma.

Keywords: Chronic respiratory failure, mepolizumab, severe asthma.

(C) 202I Sociedade Portuguesa de Alergologia e Imunologia Clínica. Published by Publicações Ciência \& Vida. This is an open access article under the CC BY-NC-ND license (http://creativecommons.org/licenses/by-nc-nd/4.0/). 


\section{RESUMO}

A asma grave é definida como sendo refratária à terapêutica máxima otimizada ou que é apenas controlada por terapêutica com efeitos secundários não toleráveis. Os agentes biológicos constituem alternativas em doentes com asma grave com inflamação tipo 2. Descrevemos o caso de uma doente com asma grave com inflamação tipo 2 de longa evolução, em que predominavam a ausência de controlo de sintomas e a necessidade de corticoterapia sistémica e concomitantemente insuficiência respiratória crónica característica diferenciadora relativamente a outros casos de asma grave.

Palavras-chave: Asma grave, insuficiência respiratória crónica, mepolizumab.

(C) 2021 Sociedade Portuguesa de Alergologia e Imunologia Clínica. Publicado por Publicações Ciência \& Vida. Este é um artigo Open Access sob uma licença CC BY-NC-ND (http://creativecommons.org/licenses/by-nc-nd/4.0/

\section{INTRODUCTION}

A sthma is one of the most common chronic diseases worldwide. Incidences amongst general population ranging from I to $18 \%$ have been described.

Severe asthma accounts for 4 to $10 \%$ of all asthma cases. It is defined as uncontrolled disease despite adherence with maximal optimized therapy and treatment of contributory factors and comorbidities, that worsens when high dose treatment is decreased or that can only be controlled with therapies that have intolerable side effects ${ }^{1,2}$. It is associated with substantial morbidity and mortality ${ }^{3}$. Its burden is incredibly high, either considering life quality or healthcare related costs ${ }^{3}$. In Portugal, asthma in adults accounts for over $2 \%$ of total healthcare costs, with uncontrolled disease costs being more than double of controlled disease ${ }^{4}$.

Individualized therapy based on asthma endotype is being pursued and is currently recognized as a more efficacious alternative for patients with symptoms refractory to guideline-based therapies'.

Monoclonal antibodies that target interleukin (IL)-5 have shown favorable results in clinical trials, with evi- dence of reductions in asthma exacerbations and other important clinical outcomes'.

\section{CASE DESCRIPTION}

We present the case of a 56-year-old woman with a 40-year long history of asthma and allergic rhinitis. She reported specific allergen immunotherapy during childhood (no further information provided), with poor results. No smoking habits, significant exposure or other medical or surgical relevant diseases.

The patient was sent to our Asthma outpatient clinic by her general physician due to uncontrolled respiratory symptoms, with an asthma control test (ACT) score of 14 and control of allergic rhinitis and asthma test (CARAT) score of 18. At this point, she was already medicated with low dose inhaled corticosteroid, long acting beta agonist, long acting antimuscarinic, nasal corticosteroid and anti-histamine. She was still presenting three to four exacerbations per year, all of which needing systemic corticosteroid to achieve symptom control. She identified the disease as a major factor of poor quality of life, recognizing a great impact on her everyday working and leisure activities. 
Initial blood tests revealed high eosinophil count (13,5\%; 1070/L) and total imunoglobulin E of $81.8 \mathrm{UI} / \mathrm{mL}$. Pulmonary function tests (PFT) at rest displayed a severe obstructive defect with $\mathrm{FEV}$, of $570 \mathrm{ml}(26 \%)$ and $\mathrm{FEV}_{/} / \mathrm{FVC}$ index after bronchodilation of $47 \%$ (fractional exhaled nitric oxide is not available at this hospital). Arterial blood gas test at rest showed a low $\mathrm{pO}_{2}(64 \mathrm{mmHg})$, with normal $\mathrm{pCO}_{2}(4 \mathrm{I}$ $\mathrm{mmHg}$ ). The only pathological finding on chest computed tomography (CT) with contrast was generalized bronchial thickening. Six-minute walk test was consistent with desaturation with exercise (T90 of $60.4 \%$ with minimal value of peripheral oxygen saturation of $86 \%$ ) and short walking capacity ( 276 meters, $56.4 \%$ of predicted value). Bronchoscopy was innocent, as well as the cytological, bacterial and mycobacterial exams of bronchial secretions and bronchoalveolar lavage, which displayed macrophages and inflammatory cells, without neoplasic findings. Skin prick tests performed in our hospital were negative, which could explain the poor results to specific allergen immunotherapy during childhood. Echocardiography was normal.

Therapy was progressively increased, with establishment of high dose inhaled corticosteroid and leukotriene receptor antagonist. Comorbidities known to worsen asthma, such as gastroesophageal reflux disease, were considered and properly addressed. Obesity and obstructive sleep apnea syndrome were ruled out (body mass index $26 \mathrm{~kg} / \mathrm{m}^{2}$ ). Ambulatory oxygen therapy to use during exercise was started.

During the first two years of follow up, the patient was evaluated every three to four months. The fact that she always presented with uncontrolled symptoms (ACT scores ranging from 12 to 18, CARAT scores ranging from 18 to 24 and AQLQ scores of 3 to 4 ) and the sustained need of oral corticosteroids on top of the above implemented strategies, along with the exclusion of differential diagnosis such as Churg-Strauss syndrome and allergic bronchopulmonary aspergillosis, led to the diagnosis of severe eosinophilic asthma.

Subsequent blood tests consistently showed elevated blood eosinophil count and PFT also had similar findings to the ones previously described. Six-minute walking test showed that oxygen therapy had improved desaturation but no change in walking distance was noticed.

The patient underwent cardiopulmonary exercise testing, with abnormal findings due to obstructive disease. She was enrolled in an exercise program which went on for three months, with a slight positive impact on dyspnea and on walking distance in the six-minute walking test (325 meters, $67.2 \%$ of predicted value).

Anti-IL-5 therapy with mepolizumab was initiated. After the first dosis, immediate improvement was perceived regarding symptom control (ACT score 22, CARAT score 28 and AQLQ score 6). Within four months, ambulatory oxygen therapy was ceased, with arterial blood gas test at rest displaying a better than ever value of $\mathrm{pO}_{2}(74 \mathrm{mmHg})$ and six-minute walking test with no desaturation and a walking distance of $370 \mathrm{~m}(77.7 \%$ of predicted value). Regarding PFT, FEV, was $1060 \mathrm{ml}$ (50.3\%) and $\mathrm{FEV}_{1} / \mathrm{FVC}$ index was $51 \%$ after 18 months. Blood eosinophil count decreased with time, with values of $9 \%$ (620/L) at 6 months evaluation and I\% (60/L) at 18 months.

Table I summarizes clinical, laboratory and functional data.

For the time being, she has completed 18 months of therapy with mepolizumab. ACT scores are invariably over 23, no admissions to the emergency department or the wards were registered and there was no demand of systemic corticosteroid therapy. Moreover, inhaled corticosteroid dose was reduced and long acting antimuscarinic discontinued.

The patient has now no limitations in her everyday life and acknowledges biologic therapy as a life changing therapeutic option.

\section{DISCUSSION}

From a functional point of view, asthmatic patients may develop chronic irreversible airflow limitation. It develops as a physiological consequence of chronic airway 
Table I. Clinical, laboratory and functional findings over time

\begin{tabular}{|c|c|c|c|c|c|c|}
\hline & $\begin{array}{c}\text { Initial } \\
\text { evaluation }\end{array}$ & $\begin{array}{c}\text { After } \\
\text { therapeutical } \\
\text { optimization }\end{array}$ & $\begin{array}{c}4 \text { months } \\
\text { after } \\
\text { mepolizumab }\end{array}$ & $\begin{array}{c}6 \text { months } \\
\text { after } \\
\text { mepolizumab }\end{array}$ & $\begin{array}{c}\text { I } 2 \text { months } \\
\text { after } \\
\text { mepolizumab }\end{array}$ & $\begin{array}{c}\text { I8 months } \\
\text { after } \\
\text { mepolizumab }\end{array}$ \\
\hline ACT score & 14 & 18 & 22 & 24 & 25 & 25 \\
\hline CARAT score & 18 & 24 & 28 & 29 & 29 & 30 \\
\hline AQLQ score & 3 & 4 & 6 & 6 & 7 & 7 \\
\hline Blood eosinophil count (\%; /L) & $13.5 ; 1070$ & $13 ; 910$ & - & $9 ; 620$ & - & $1.1 ; 60$ \\
\hline FEV I (ml; \%) & $570(26)$ & $860(40)$ & - & - & - & $1060(50.3)$ \\
\hline $\begin{array}{l}\text { FEVI/FVC after } \\
\text { bronchodilatation (\%) }\end{array}$ & 47 & 49 & - & - & - & 51 \\
\hline pO2 in blood gas test $(\mathrm{mmHg})$ & 64 & 63 & 74 & 73 & 77 & 76 \\
\hline T90 in 6 minute walk test (\%) & 60.4 & - & 4.3 & - & - & - \\
\hline $\begin{array}{l}\text { Walking capacity in } 6 \text { minute } \\
\text { walk test (meters; \%) }\end{array}$ & $276 ; 56.4$ & - & $370 ; 77.7$ & - & - & - \\
\hline
\end{tabular}

ACT - asthma control test; CARAT - control of allergic rhinitis and asthma test; AQLQ - asthma quality of life questionnaire

inflammation and remodeling, which includes large airway epithelial basement membrane thickening, airway wall oedema and airway smooth muscle hyperplasia and hypertrophia ${ }^{5}$. There is little radiological evidence of lung destruction in non smokers asthmatics. The long term consequences of these findings are not fully known ${ }^{5}$.

Adult population with asthma may present with other comorbidities, such as cardiac failure, chronic obstructive pulmonary disorder and obstructive sleep apnea syndrome, which can contribute to impaired gas exchanges. Furthermore, increasing evidence suggests that asthma may be associated with greater risks of pulmonary embolism ${ }^{6}$ which could obviously contribute to respiratory failure. Chronic respiratory failure exclusively due to asthma is an uncommon event, as documented in a retrospective study of a population of patients under long term oxygen therapy ${ }^{5}$.

In patients with severe asthma, both common clinical features and rarer consequences such as respiratory failure are difficult to address and control. Biological therapy has shown promising results in many studies over the past few years and its implementation has undoubtedly enhance the approach to patients with severe asthma. The fact that it constitutes a targeted therapy makes it more effective, with better and faster results.

Overproduction of IL-5 was first linked to asthma in the 1990s. To this date, many studies have evidenced a central role for IL-5 and eosinophilic airway disease, hence the development of IL-5 targeted therapy'. Mepolizumab and reslizumab are humanized monoclonal antibodies that bind IL-5 and benralizumab is a humanized monoclonal antibody that binds to the IL-5 receptor alpha subunit ${ }^{7}$.

Mepolizumab is the most studied anti-IL-5 in the treatment of severe asthma and was the first agent in its class to be tested in a clinical trial ${ }^{8}$. Evidence has emerged on several benefits with mepolizumab therapy in patients with severe eosinophilic asthma. It has proved to reduce sputum and blood eosinophil count ${ }^{8,9}$, improve symptom control and lung function ${ }^{8}$ and decrease asthma exacerbations ${ }^{3,8}$ and systemic corticosteroid use $\mathrm{e}^{8,10}$.

All in all, this is a case of a patient with uncontrolled asthma symptoms that negatively affected her life quality. 
Moreover, we believe that severe asthma itself led to chronic respiratory failure that met criteria to ambulatory oxygen prescription. The onset of mepolizumab was of the upmost importance, as illustrated by the positive outcomes above described.

\section{CONCLUSION}

This case highlights the relevant role of biological therapy in severe asthma. The presence of respiratory failure that improved so rapidly after the onset of mepolizumab therapy is probably what differentiates it the most from other cases of severe asthma with a favorable response to treatment.

\section{Conflito de interesses}

Os autores declaram que não existem conflitos de interesses.

\section{ORCID:}

Joana Branco (iD) 0000-0002-9520-2435

Filipa Todo Bom (iD) 0000-0001-9484-915X

Sofia Furtado (iD) 0000-0002-0268-4595

Contacto:

Joana Branco

E-mail: joanaafonsobranco@gmail.com

\section{REFERENCES}

I. Patel SS, Casale TB, Cardet JC. Biological therapies for eosinophilic asthma. Expert Opin Biol Ther 2018;18:747-754. doi: I0.1080/147/2598.2018.1492540

2. 2020 GINA Report, Global Strategy for Asthma Management and Prevention.

3. Pavord ID, Korn S, Howarth P, Bleeckers ER, Buhl R, Keene ON, et al. Mepolizumab for severe eosinophilic asthma (DREAM): a multicentre, double-blind, placebo-controlled trial. Lancet 2012;380: 65I-59. doi: 10.1016/S0I40-6736(I2)60988-X.

4. Barbosa JP, Magalhães MF, Sousa AS, Azevedo LF, Fonseca JA. Cost of asthma in Portuguese adults: A population-based, cost-of-illness study. Rev Port Pneumologia (2006) 2017;23:323-330. doi: 10.1016/j.rppnen.2017.07.003.

5. Caramori G, Fabbri M, Paioli D, Falcone F, Severino C, Felisatti $\mathrm{G}$, et al. Asthma is not a common cause of severe chronic respiratory failure in non-smokers: ALOT study. Monaldi Arch Chest Dis 2005;63:84-87. doi: 10.4081/monaldi.2005.643.

6. Lee P, Fu P. Pulmonary Embolism and Severe Asthma: Case Report and Literature Review. Medicina (Kaunas) 2019;55:647. doi: 10.3390/medicina55100647.

7. Hambly N, Nair P. Monoclonal antibodies for the treatment of refractory asthma. Curr Opin Pulm Med 2014;20:87-94. doi: 10.1097/MCP.0000000000000007.

8. Giannetti MP, Cardet JC. Interleukin-5 antagonists usher in a new generation of asthma therapy. Curr Allergy Asthma Rep 2016;16:80. doi: 10.1007/s/1882-016-0662-I.

9. Mukherjee M, Sehmi R, Nair P. Anti-IL5 therapy for asthma and beyond. World Allergy Organ J 2014;7:32. doi: 10.1186/1939-455I$-7-32$.

10. Bel EH, Wenzel SE, Thompson PJ, Prazma CM, Keene ON, Yancey SW, et al. Oral glucocorticoid-sparing effect of mepolizumab in eosinophilic asthma. N Engl J Med 2014; 371:I 89-97. doi: 10.1056/ NEJMoal40329I. 